MANCHESTER

1824

눈

Economics

Discussion Paper Series

EDP-1603

\title{
The Political Economy of National Statistics
}

Diane Coyle

September 2016

Economics

School of Social Sciences

The University of Manchester

Manchester M13 9PL 


\section{The political economy of national statistics}

Diane Coyle

University of Manchester ${ }^{1}$

"Though the Social Product (or National Income, or Gross National Product) has been 'sold' to the public, it has been 'sold' by economists. We have a responsibility for it - the responsibility of the manufacturer for the quality of the good which he sells. We cannot escape the duty of justifying it by pretending that it has been justified already."

J R Hicks ${ }^{2}$

The political economy of national statistics is relatively unexplored territory. What could shift the focus from GDP growth as the primary measure of economic success to other measures widely recognised in the 'beyond GDP' debate as desirable indicators of economic welfare? For probably the first time since the 1950s, there is a broad coalition in favour of such a shift; but this has not coalesced around a single framework. Instead, there is a proliferation of alternative approaches.

This paper models the setting of standards for statistics as a game with multiple potential equilibrium outcomes, and considers the conditions for a switch from the prevailing standard to a new one. The possibility of a switch depends on the degree of agreement or co-ordination on an alternative standard; there will be a coalition large enough to tip the outcome to a new equilibrium. I suggest this is more likely to occur if there is a foundation in economic theory around which economists and policymakers can coalesce - the role played by Keynes's macroeconomics in the creation of today's national accounting standards. Statistics inevitably lag the reality they are meant to describe. When there is structural change in the economy (as now, due to digital transformation, globalization and sustainability concerns), the gap between statistics and reality may be so great that the lock-in to the existing statistical framework due to the constellation of interests involved (statisticians, economists, politicians, lobbies, voters) can break. I conclude that the pressures for change are now so strong that an effective international coalition to develop a new national statistical framework, better measuring the changed structure of the economy and economic welfare, might be possible.

\section{Introduction}

There has been a surprising amount of debate about national statistics in recent years. Although there have been critics of the centrality of GDP growth in economic policy throughout the postwar lifetime of modern national accounting, their critiques seem to have been gaining fresh traction. In addition to longstanding questions about

\footnotetext{
${ }^{1}$ My thanks to Tim Besley, Joe Grice, Cameron Hepburn, Gregor Semieniuk and Peter Sinclair, and the participants at the INET Wealth conference in June 2016 for their helpful comments on earlier drafts. I am of course responsible for all errors and omissions. Prepared as a chapter in 'Wealth', eds Kirk Hamilton and Cameron Hepburn, forthcoming.

2 The Scope and Status of Welfare Economics Author(s): J. R. Hicks Source: Oxford Economic Papers, New Series, Vol. 27, No. 3 (Nov., 1975), pp. 307-326 Published by: Oxford University Press Stable URL: http://www.jstor.org/stable/2662172
} 
environmental sustainability and the omission of home production, there has been increasing interest in the direct measurement of well-being. ${ }^{3}$ Recently, questions about the effect of digital technologies on the understanding and measurement of the economy have also come to prominence. ${ }^{4}$

The debate is gaining increasing official recognition. One important milestone was the Sen-Stiglitz-Fitoussi Commission, established by President Sarkozy of France, which provided in its 2009 report a rigorous and high-profile assessment of the shortcomings of the conventional focus on GDP growth. ${ }^{5}$ A programme of work at the OECD and in the European Commission has followed up this work with the 'GDP and Beyond' agenda. ${ }^{6}$ The UK's Chancellor of the Exchequer commissioned an independent review of economic statistics whose remit specifically included in addition the question of whether official economic statistics are capturing digitallydriven structural change in the economy. It concluded not, and encouraged official statisticians to lead an international debate on modernising economic statistics. ${ }^{7}$

The current salience of economic measurement in public debate is a reflection of the growing mismatch between the statistical framework created more than 70 years ago and current structural economic change and political events. In his landmark 1958 history of national accounting, Paul Studenski emphasised that measuring national income has always depended on both the state of economic theory prevailing at the time and the historical context - the presence of war or crisis, tax and fiscal needs, and also rapid technological and structural change, such as the transition from agriculture and growth of manufacturing before and during the Industrial Revolution. ${ }^{8}$ We are well into such a period of rapid change in the structure of the economy and society, due to digital technology, globalization and social change. The lag between the statistical measurement framework and the structure of the economy is therefore larger now than in past decades.

However, national accountancy is a matter of politics and administration as well as economic debate. 'Statistics' originated as the systematic collection of quantitative information the state needed to fulfil its functions effectively. ${ }^{9}$ In a modern democracy, trusted official statistics are vital to enable citizens to hold the state to account. ${ }^{10}$ National statistics are increasingly being used for so-called 'administrative' purposes such as devising and applying fiscal regimes, updating benefit payments, setting the

\footnotetext{
${ }^{3}$ For example, D Meadows et al, The Limits to Growth, first pub. Universe Books,1972; Stern Review http://webarchive.nationalarchives.gov.uk/20100407011151/http://www.hmtreasury.gov.uk/stern_review_report.htm accessed 29/1/16; E Mishan 1993 The Costs of Economic Growth, revised edition, Oxford University Press ch 12; Richard A Easterlin. 'Does Economic Growth Improve the Human Lot? Some Empirical Evidence.' In Paul A. David and Melvin W. Reder, eds., Nations and Households in Economic Growth: Essays in Honor of Moses Abramovitz, New York: Academic Press, 1974.

${ }^{4}$ See summary in Bean (2016),

${ }^{5}$ Insee, Rapport de la Commission sur la mesure des performances économiques et du progrès social, 2009, http://www.insee.fr/fr/publications-et-services/default.asp?page=dossiers_web/stiglitz/documentscommission.htm

${ }^{6}$ http://www.oecdbetterlifeindex.org/\#/11111111111,

http://ec.europa.eu/environment/beyond_gdp/index_en.html

${ }^{7}$ Bean, op cit

${ }^{8}$ Paul Studenski, The Income of Nations, New York University Press, 1958, pp158-159.

${ }^{9}$ Alain Desrosières, The Politics of Large Numbers: A History of Statistical Reasoning, Harvard University Press, 1998.

${ }^{10}$ Diane Coyle, Talking About the National Accounts: Statistics and the Democratic Conversation, University of Manchester Economics Discussion Paper EDP-1506, May 2015.

http://www.socialsciences.manchester.ac.uk/medialibrary/economics/discussionpapers/EDP-1506.pdf Forthcoming in Review of Income and Wealth.
} 
terms in financial contracts, and so on. Governments implement important public policy agendas informed by their ambitions for GDP growth rates as compared with the past or compared with other countries. ${ }^{11}$ Policies in many domains are appraised and evaluated in terms of their contribution to GDP growth. Many stakeholders (including national statisticians, politicians, economists, lobby groups, and the media and public) have invested a good deal in the existing statistical framework, and the need to co-ordinate change means there is considerable lock-in to the existing statistical standards.

The next section begins by discussing the growing gap between the current standard statistical definitions, with a strong public focus on GDP growth, and the structure of the economy. There are several reasons for considering the current framework to be an increasingly inadequate representation of underlying economic reality.

The following sections discuss how politics determine the definition of statistical concepts and the measurement of the economy; and in turn how economic statistics feed back to politics, with both arms of the feedback loop taking authority from economic theory. There are fewer examples of political impact on statistical definitions, so it is interesting to note the circumstances in which changes can occur.

The two-way interaction within a set of rules shaped by prevailing economic theory is presented in Section 5 as a game whose equilibrium outcome is hard to shift. There are numerous forces of inertia, requiring a co-ordination effort to bring about a move from one key statistical focus to another, although these have occurred on occasion. However, in a simple model of co-ordination a 'tipping coalition' is possible.

The game is highly simplified, given the multiple actors involved in the setting and acceptance of statistical standards - statisticians themselves, economists, politicians and public. Yet it captures the character of a switch to a new standard, as illustrated in the brief description here of the origins of modern national income accounting in the specific historical context of the World War II and theoretical context of Keynesian macroeconomics. The turn during the Cold War from using national accounts as a tool to manage the level of GDP to focusing on the growth of real GDP provides a striking example of the interaction between politics, statistics and economic theory.

Much of this historical debate centred on a key issue relevant to current challenges to the primacy of GDP growth as a policy goal, namely the distinction between a measure of activity and measurement of economic welfare. This issue is at the heart of the current discussion about statistics, as the gap between marketed activity measured by GDP and economic welfare may be increasing.

I conclude that this wedge between welfare and statistics, between reality and definitions, may now be sufficiently large that a co-ordination effort could bring about a shift in the political and policy focus away from GDP growth. This may occur in a limited way, within the existing intellectual framework of the post-war System of National Accounts (SNA), unless there is a concurrent change in economic theory. For the 'rules of the game', within which the economic measurement and political choices interact, are set by the intellectual framework provided by prevailing economic theory. The SNA co-evolved with Keynesian aggregate economic theory,

\footnotetext{
${ }^{11}$ Jochen Hartwig, 'On Spurious Differences in Growth Performance and on the Misuse of National Accounts for Governance Purposes', Review of International Political Economy, Vol. 13, No. 4 (Oct., 2006), pp. 535-558.
} 
bolted on to neoclassical welfare economics. It is harder to see radical change in economic measurement without a theoretical 'paradigm shift' to an alternative framework, alongside the institutional effort of international co-ordination. ${ }^{12}$

The ever-wider gap between the existing SNA framework and economic welfare, given recent significant structural change in the economy as well as a growing scientific emphasis on sustainability, means the pressure for change is increasing. Coalition-building to overcome the current standards 'lock-in' may therefore be successful.

\section{The growing gap between economic statistics and the economy}

For a number of reasons, dissatisfaction with the current framework of national statistics is growing.

\section{The financial crisis and income distribution}

The post-crisis period of slow-to-negative growth in median real incomes particularly affecting the middle and lower deciles in the OECD income distribution has coincided with an increased awareness of inequality, and of the possible adverse effects of automation on employment, along with concern about the possible impacts of large-scale immigration. Many people have noted in particular the greater inequality of incomes in almost all OECD countries, and slow real income growth among their middle classes (and perhaps median voters). Branko Milanovic calls this group the 'decile of discontent', as it is the only decile of the global income distribution not to have experienced real income growth since $1980 .{ }^{13}$ Although the big increase in inequality predates the 2008-09 crisis by 20 years, and has levelled off since then, the economic shock of the crisis means inequality has been widely observed and discussed. ${ }^{14}$ The phenomenon of Thomas Piketty's book Capital in the $21^{\text {st }}$ Century speaks to this political salience. Many media commentators, and distinguished economists, have started to query the value of additional GDP growth that does not benefit most citizens. This salience challenges the convention of considering the growth of output and the distribution of output separately, seeing distribution as a distinct, normative political question.

\section{The digital sector}

Many participants believe the digital sector's contribution to growth and productivity is being under-stated in official GDP growth and productivity statistics. More recently, the digital sector has started to question the validity of official growth statistics. Many people in technology businesses firmly believe current statistics understate the importance of the sector. For example, Hal Varian, chief economist at Google, said in a newspaper interview: "There is a lack of appreciation for what's happening in Silicon Valley because we don't have a good way to measure it."15 Whether correct or not in arguing that the statistics underplay its importance, the industry has sufficient influence that this argument is heard by politicians, especially as growth and productivity performance has been disappointingly below-trend for almost a decade

\footnotetext{
12 Thomas Kuhn, The Structure of Scientific Revolutions, first publ.1962

${ }^{13}$ B Milanovic, Global Inequality: A New Approach for the Age of Globalization, Harvard University Press, 2016.

${ }^{14}$ For recent trends see OECD (2015), http://www.oecd.org/social/income-inequality-9789264246010en.htm

${ }^{15}$ Silicon Valley Doesn't Believe U.S. Productivity Is Down, Timothy Aeppel, Wall Street Journal, 16 July 2015, http://www.wsj.com/articles/silicon-valley-doesnt-believe-u-s-productivity-is-down-1437100700
} 
in many OECD economies. Concern about productivity has been one of the factors contributing to political interest in statistical issues.

There are several ways in which conventional GDP statistics fail to record important digitally-driven changes in the underlying structure of business and the economy, ranging from shortcomings in data collection methods, to a lack of invariance to business model changes, to deep methodological questions. ${ }^{16}$ It is certainly the case that the sector's share in nominal GDP has grown surprisingly little, but this probably reflects rapidly falling prices. The statistics probably understate price declines. Hedonic price adjustments in the deflator ought to correct for the corresponding quality change in calculating real GDP growth, but are unlikely to have done so fully, leading to an under-measurement of real GDP growth. For example, the total weight in the Consumer Price Index basket of items whose prices are hedonically adjusted (such as mobile phone handsets and tablets) is less than 5 per 1000 in the UK, while in the US there is no hedonic adjustment for digital consumer goods. ${ }^{17}$ Price indices, already made complex by hedonic adjustments for quality improvements in digital devices, do not take account of common pricing structures such as bundling and twosided pricing decisions. Furthermore, typically one side of a platform market will be cross-subsidised by the other, so the inclusion of just one price in an index will ignore the cross-subsidy element. ${ }^{18}$ It is clear that the Standard Industrial Classification and Standard Occupational Codes do not enable adequate statistical capture of the new sectors: there are 50 categories of 'painter' in the SOC but none relating to jobs in software, online activity, social media etc.

The existing framework makes it difficult, too, to measure the consumption of 'free' digital goods, and output and growth measures are not invariant to the choice of business model as between subscription and advertising-funded. Subscription payments are straightforward to capture in domestic GDP aggregates, whereas online advertising revenues largely go to major US digital corporations, and no adjustment or imputation is made for the consumer 'expenditure' of looking at adverts. ${ }^{19}$ The growing provision of 'voluntary' production of free online goods, from open source software to YouTube channels, is blurring the conventional production boundary - long challenged by those who believe home production (cooking, cleaning, caring) and volunteering should be included in any measure of aggregate economic output. While excluding reading to children at the local school or volunteering at the charity shop might be considered small in scale, so a forgivable omission, it is harder to ignore the growing economic value being created by open source software, the proliferation of entertainment or educational content being volunteered online, or resources such as Wikipedia or Wolfram Alpha. Finally, GDP represents, "The aggregated value of the production of goods and services within the field of socially organized employment," ${ }^{20}$ yet the organization of employment is changing rapidly via digital platforms and the growth of self-employment, as well as outsourcing and the casualization of the labour force.

\section{Environmental concerns}

\footnotetext{
${ }^{16}$ D Coyle, 'Modernising Economic Statistics: Why It Matters', National Institute Economic Review, November 2015, pp. F4-F7.

${ }^{17}$ See http://webarchive.nationalarchives.gov.uk/20160105160709/http://ons.gov.uk/ons/rel/cpi/reviewof-hedonic-quality-adjustment-in-uk-consumer-price-statistics-and-internationally/2014/index.html and http://www.bls.gov/cpi/cpihqaitem.htm

$18 \mathrm{~J}-\mathrm{C}$ Rochet and J Tirole, 2006.

${ }^{19}$ See Coyle, op cit.

${ }^{20}$ Vanoli, op cit, p242.
} 
Almost as soon as GDP growth became established as an official OECD policy target in 1961, environmentalists and some economists started to question its welfare consequences. The work that led to the 1972 Club of Rome report, The Limits To Growth, had started in the 1960s. Also in 1972, William Nordhaus and James Tobin advocated a 'Measure of Economic Welfare' adjusting real GDP per capita downward for environmental externalities, and for spending on 'regrettables' such as defence and policing, and adjusting it upward for the value of leisure and the value of home production. ${ }^{21}$ All of these types of adjustment have been echoed in later critiques of GDP, and reflected in a range of proposed alternatives such as the Genuine Progress Index, or the Index of Sustainable Economic Welfare. A parallel stream of work has focused on measuring natural capital (or 'comprehensive wealth') in order to at least supplement the flow measure of economic activity with a measure of balance sheet environmental wealth or change in assets. This includes attempts to measure environmental externalities such as pollution. ${ }^{22}$ The environmental impact of economic growth is perhaps becoming ever more obvious, from evidence of the effects of global climate change to more local pollution impacts of Asian industrialisation, or biodiversity losses. Such phenomena are refracted through domestic politics in many countries. For example, public concern about dire air quality in China's cities, and other evidence of serious environmental degradation, drove the emphasis on addressing climate change and energy policy in the government's $12^{\text {th }}$ Five Year Plan. ${ }^{23}$ Environmental campaigners and green parties remain, not surprisingly, leading campaigners for alternative economic and social measurements.

On all three fronts - environmental change, the post-crisis economy and inequality, technological change - and perhaps others such as globalisation and shifts in geopolitical power, changes in the world are contributing to an uncomfortable gap between existing national statistics and the underlying drivers of economic welfare. This helps explain the greater traction of alternative approaches to economic statistics - including in policy fora like the OECD and European Commission - in the past few years. The conditions are perhaps ripe for a significant change in the statistical framework, of the kind noted by Studenski. As he wrote of the interwar years, when the building blocks for the national accounts were being created: "National income estimates of this period were designed to reveal changes that had taken place in the structure of the national economy as a consequence of World War $\mathrm{I}$, or that were taking place currently under the impact of new technological change and worldwide social, economic and political developments." ${ }^{4}$

The Fitoussi-Sen-Stiglitz Commission was an important moment in recent times, providing a thorough assessment of the arguments for measuring social and environmental impacts and whether these could be used to construct an adjusted GDP, concluding that a 'dashboard' approach including a range of indicators was better than aiming to collapse many dimensions of economic welfare into one index, requiring decisions about weightings and trade-offs. As Fleurbaey and Blanchet put it, "Aggregation always implies assuming some more or less important substitution possibilities between the items that are aggregated." 25 This programme has been

\footnotetext{
${ }^{21}$ W D Nordhaus, J Tobin, 'Is Growth Obsolete?,' in Economic Research: Retrospect and Prospect, Vol

5, Economic Growth, NBER, (1972).

${ }^{22}$ Dieter Helm, Natural Capital: Valuing the Planet, Yale University Press (year)

${ }^{23} \mathrm{http}: / /$ www.china.org.cn/china/2010-10/27/content_21214648.htm

${ }^{24}$ Studenski, op cit, page 149

${ }^{25}$ Marc Fleurbaey, Didier Blanchet, Beyond GDP: Measuring Welfare and Assessing Sustainability,

Oxford University Press, 2013.
} 
taken forward by 'dashboard' alternatives such as the European Commission's 'GDP and Beyond' work including the Social Progress Indicator, and the OECD's Better Life Index. In several countries there are processes looking at statistical frameworks. New Zealand has established a formal well-being framework for measurement, while the UK's Office for National Statistics has had one since 2011. The UK also has one of the most advanced sets of natural capital accounts. In the Netherlands there has been a parliamentary inquiry into the relevance of statistics to sustainability.

The present dissatisfaction speaks also to the historical debate about whether the aim of national or 'social' accounts ought to be the measurement of economic welfare, or simply economic activity. I return to this in Section 6 below.

\section{How politics shape economic statistics}

Events and structural changes in the economy, their theoretical conceptualisation by economists, their construction and measurement by statisticians, their use in political debate, and economic policy, all mutually influence each other (see figure 1). As Adam Tooze puts it in his history of statistics in early $20^{\text {th }}$ century Germany: "Statistics are not neutral reflections of social and economic reality. They are produced by particular social actors in an effort to make sense of the complex and unmanageable reality that surrounds them.. ${ }^{26}$ The statistics consequently help shape the reality, as much as reality determines which statistics are defined and collected. The development of national statistics as a category was profoundly important for the development of bureaucratic government in nation states, and the application of policies to 'the economy'. ${ }^{27}$ Macroeconomic measures, especially GDP growth, are powerful ideas used to legitimize specific courses of government action. ${ }^{28}$

Figure 1: Mutually reinforcing elements of the statistical framework

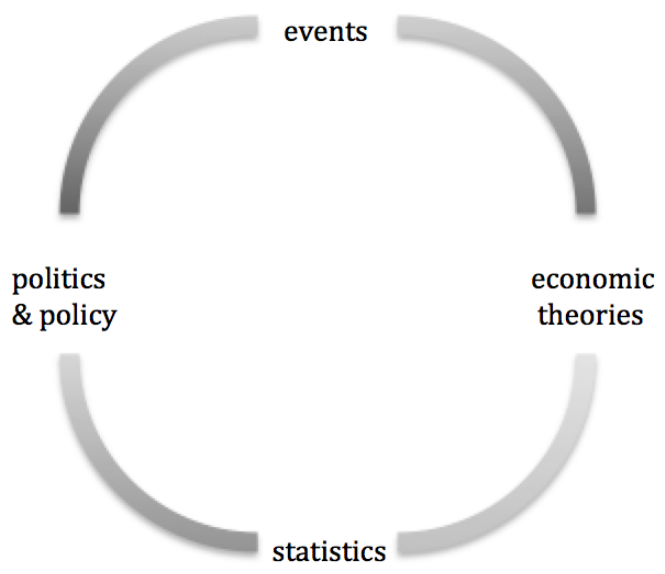

There are some important examples of politic developments affecting the use of economic statistics within the broader framework of the SNA and the assumed

\footnotetext{
${ }^{26}$ Adam Tooze, Statistics and the German State, 1900-1945: The Making of Modern Economic Knowledge, Cambridge University Press 2007, p 3.

${ }^{27}$ Desrosières, op cit.

${ }^{28}$ Mugge op cit.
} 
priority of economic growth. The influence of specific events changes the political focus on certain existing economic statistics over time, in obvious ways. A crisis will lead to greater interest in the media, economics journals, and broader commentary on specific measures. Examples include public focus on the unemployment rate, the government budget deficit or debt ratio, or inflation during the 1970 s oil shocks.

Sometimes the influence of statistics on policies and political choices is intentional. Target-setting is an interesting type of example of the mutual influence of economic events, political pressures and theory. The Millennium Development Goals, for example, were intended to ensure governments prioritised the selected outcomes. The Maastricht Treaty criteria limiting budget deficits were at least in part meant to give some member governments the external incentive or rationale for tighter fiscal policies. Setting monetary growth targets as a number of countries did in the late 1970 s and 1980s was similarly meant as a constraint limiting the range of politicians' decision-making freedom. A number of governments in the late 1970s and early 1980s pursued monetary targeting as a means of reducing inflation and increasing real economic growth. These included the US and UK governments. Thus the UK Treasury's 'Medium Term Financial Strategy' documents published with the annual Budget set a maximum for the growth of specific monetary aggregates, initially a broad and a narrow money measure, Sterling M3 and MO (cash in circulation and sight deposits). Subsequently, the previously stable velocity of circulation for both measures increased, and the two series grew at a far faster pace than the target. This phenomenon of a structural relationship on which a target was based altering because the target-setting changes underlying behaviour is now variously known as the Lucas Critique or Goodhart's Law.

Everyday statistics can become highly politically contested, in the sense that political parties will use them to try to substantiate particular claims, often by presenting the statistics in ways most favourable to their arguments or - if they have the power to do so - changing definitions or methodology in 'helpful' ways. Examples abound. For instance, the UK's unemployment statistics were hotly disputed during the 1980s; unemployment was rising quickly, and the Government introduced a sequence of methodological changes to the statistics, each of which decreased the headline total. This was one of the examples leading ultimately to the independence of the Office for National Statistics from direct ministerial control. The Greek Government manipulated its nominal GDP figures upward and its budget deficit figures downward in the early 2000s, to reduce the deficit to GDP ratio in order to qualify for Euro membership. (It did qualify, even though Eurostat officials had not accepted the national accounts - indeed, rejected them in a strongly worded report.) Yet in 2014-15, some Greek politicians claimed the latest GDP figures were being understated, making the country more dependent on the international bailout than they believed necessary. The national statistician, Andreas Georgiou, was accused of treason. He resigned in 2016; Greece's international creditors insisted his replacement must be appointed by an international panel of distinguished statisticians. ${ }^{29}$

Industry lobbying can also lead to political pressure on apparently technical methodological changes. There have always been difficult methodological questions about the financial sector, concerning the extent to which financial services should be considered a final product rather than an intermediate good, and how to value services with no explicit price as they rely on an interest spread. However, every

${ }^{29}$ Coyle. GDP, chapter 1. 
definitional refinement in the SNA has led to an upward revision in the apparent size of the sector, and helped the sector make the case for global financial deregulation on the basis that finance contributes significantly to economic growth. ${ }^{30}$ This example is particularly interesting in the light of the digital sector's current view that its contribution to the economy is not well reflected in the GDP statistics, as noted above. The finance example suggests that specific sectors can successfully contribute to the forces for definitional changes in the statistical standards.

In order to try to minimize the scope to use statistics as political footballs, all OECD countries' national statistical offices are now formally independent, although with a variety of governance arrangements. ${ }^{31}$ However, the growing 'administrative use' of GDP in international fiscal agreements such as the Maastricht Treaty, in international debt bailouts and in bond contracts is profoundly increasing the pressure for key statistics to give the 'right' answer. Similarly, tying contracts and benefits to specific inflation measures leads to intense commercial and political pressures on statistical definitions and methodology. Moreover, as the above examples suggest, public debate about the statistical framework can have an influence on the attention paid to specific statistics, and on some definitions such as measurement of a particular sector, even if not on the underlying conceptual framework of the system of national accounts.

\section{How economic statistics affect political outcomes}

The political economy literature has underlined the influence of economic decisions on political outcomes so that the economic and political equilibria are interdependent. $^{32}$ Decisions about economic statistics are particularly interesting because they are a direct input into the political process. Politicians certainly believe economic statistics affect political outcomes, and use statistics to buttress their claims of achievement or to support specific policies. Competing parties spin the same statistics different ways. So common is this pattern of competing political claims about statistics that independent 'fact checking' organisations have emerged.

In research on this question, economic conditions are measured by standard economic statistics, related to them in what André Vanoli has referred to as "the dialectic of reality and experience". ${ }^{33}$ To complicate matters, this is a mediated experience, as most voters gain their understanding of the link between their experience and economic statistics from the media or social media. With this in mind, the empirical evidence that the statistics affect voting outcomes seems robust. One survey of empirical research on US, French, British and Danish elections concludes, "For all democratic nations that have received a reasonable amount of study, plausible economic indicators, objective or subjective, can be shown to account for much of the variance in government support." The relevant macroeconomic indicator - GDP growth, unemployment or inflation - varies; but consistently, "Citizen dissatisfaction with economic performance substantially

\footnotetext{
${ }^{30}$ B Christophers, Banking Across Boundaries: Placing Finance in Capitalism, Wiley/Blackwell 2013.

${ }^{31}$ Canada's official statistical office formally reports to the government, and was controversially directed in 2010 to drop its long form census; the Trudeau government elected in 2016 has pledged to make the bureau formally independent. Mexico's statistical office became independent in 2007.

${ }^{32}$ See for example T Besley and S Coate, 'Sources of Inefficiency in a Representative Democracy: A Dynamic Analysis', American Economic Review, 88, vol 1, 139-156, March 1998.

${ }^{33}$ A Vanoli, A History of National Income Accounting, IOS Press, 2005.
} 
increases the probability of a vote against the incumbent." ${ }^{34}$ The authors also conclude that little is known about why specific economic variables come to be the focus of public attention, or about the role of the media in focusing voters' attention; this is an under-researched area.

One recent paper suggests that the components of well-being beyond traditional economic statistics might also have an influence on voting outcomes. Subjective well-being measures are correlated with the incumbent's vote share in a long-run panel of European countries, controlling for standard macroeconomic variables. ${ }^{35}$ No countries have published reported well-being statistics over time (there are just three years' worth of data in the UK).

Politicians' boasts about specific economic statistics are rational in the light of the evidence on voting. So too is their desire to find economic policies to maximise the growth rate and therefore the evaluation of policy choices in these instrumental terms. For example, the rationale for advocacy of 'structural reforms' is almost always that these are essential to boost productivity and GDP growth. While this argument draws on economic theory, it seeks ratification through regressions using available national statistics. The likely effect on GDP growth statistics is thus used as justification for contentious policies such as enhanced labour market 'flexibility', greater competition, or reduced taxes on business. ${ }^{36}$ International institutions such as the IMF and the OECD have developed a playbook of growth-enhancing policies, justified with reference to academic economic research. The international policy 'standards' can put pressure on national governments to change their policies. A further source of pressure from international standards comes from the political sensitivity to international rankings.

There are other examples of the 'performativity' of economic statistics, or in other words the role of measurement in affecting outcomes. The best-known come from the financial markets, including the development of the Fischer-Black option pricing model and the publication of price statistics calculated using the model. The availability of an accepted intellectual framework and statistics gathered on that basis made the options markets a reality. ${ }^{37}$ This is a finance model, but performativity characterises economic statistics all the way up to the scale of the national accounts.

Yet while some social or market power is required to establish certain measures as valid, once established they become extremely hard to dislodge. "Newspapers and public officials ... have very limited ability to rework the numbers into different ones. They thus become black boxes, scarcely vulnerable to challenge, except in a limited way, by outsiders. Having become official, then, they become increasingly real." 38

\footnotetext{
${ }^{34}$ Michael Lewis-Beck and Mary Stegmaier, Economic Determinants of Electoral Outcomes, Ann Rev Polit Sci 2000:3, 183-219.

${ }^{35}$ Ward, G (2015), “Is Happiness a Predictor of Election Results?”, CEP Discussion Paper No. 1343.

36 'On Spurious Differences in Growth Performance and on the Misuse of National Accounts Data for Governance Purposes', Jochen Hartwig Review of International Political Economy, Vol. 13, No. 4 (Oct., 2006), pp. 535-558

${ }^{37}$ Donald Mackenzie, 'Option Theory and The Construction of Derivatives

Markets' by Donald MacKenzie, Chapter 3, Do Economists Make Markets, ed. MacKenzie, Muniesa and Siu. Princeton University Press, Princeton NJ, 2007; Diane Coyle, The Public Responsibilities of the Economist, Tanner Lectures, 2012.

https://www.bnc.ox.ac.uk/downloads/news/tanner_lecture_2012_text.pdf

${ }_{38}$ Theodore Porter, Trust in Numbers: The Pursuit of Objectivity In Science and Public Life, Princeton University Press 1995, p42.
} 
The feedback between political forces and economic statistics means that, while significant events can change the focal statistic within the existing meta-framework from time to time, substantial changes in economic measurement involve a coordination problem. All players - economists and statisticians, politicians from different parties, and the institutions through which economic debates are mediated such as media and think tanks, and the voters - need to make the shift at about the same time. This is quite a hurdle.

The institutional process of setting statistical standards and methodologies greatly exacerbates the co-ordination problem. Since the earliest days, the SNA has been defined in a process overseen by the United Nations Statistical Commission, cascading down through international committees, involving other bodies such as the OECD and Eurostat, and finally national statistical offices. There are professional groups of statisticians, accountants and some economists also engaged in the process, whose membership will include official statisticians. The international standard setting is a consensus process involving broad consultations. It also involves a good deal of highly technical work, and those involved necessarily spend the majority of their time on this rather than on wider questions. There have been three major revisions to the SNA since 1945, the last in 2008, implemented in the European System of Accounts (ESA) in 2014. Those involved say it typically takes 15-20 years to go through the revision process. Similarly, the UN adopted a System of Environmental Economic Accounting (SEEA) formally in 2014, following a 2003 revision of a standard first set in 1993. The SEEA is based on the same principles as the SNA, "In order to facilitate the integration of environmental and economic statistics." ${ }^{39}$ In his detailed history of national accounting, Vanoli recounts the progressively more technocratic nature of the international process of standardsetting over the decades, reflecting the growing complexity of the SNA. ${ }^{40}$ This means that increasingly statisticians themselves have been key players in the process. Relatively little scholarly attention has been paid to the sociology and political economy of the international statistical world, although this is starting to change. ${ }^{41}$

Official statisticians place understandable weight on adherence to international standards. Not only has enormous intellectual effort gone into the agreed methodologies; it is also, alongside their independence, their strongest defence against the (over-)politicisation of statistics. However, like any international consensus process, it makes significant change extremely slow and difficult. No statistician ever got into trouble by sticking to the UN-approved methodology, and national statistical offices are reluctant to depart from the standards. The history of the emergence of statistical standards, and of the way the resulting statistics are used in policy, demonstrates the feedback loop between economic thinking, measurement and politics. However, updating measurement methods is harder now than in earlier periods, because the standards are set in a slow-moving international consensus process, which is complex and technocratic. Nor do statisticians agree with each other: they divide between those strongly committed to existing orthodoxy and those clear that significant change is necessary. The periodic updates to the SNA (in 1968, 1993, 2008) have each taken many years of discussion. ${ }^{42}$

\footnotetext{
${ }^{39} \mathrm{http} / / /$ unstats.un.org/unsd/envaccounting/seea.asp

${ }^{40}$ Vanoli, op cit, Appendix to Chapter 3.

${ }^{41}$ Hirschman, Mügge, op cit.

42 'Meaning and measurement of national accounts statistics', Frits Bos
} 
This means politicians and economists feel helpless to change the definitions and standards, or - like the public - simply taken them as givens without understanding the inherently judgemental character of economic statistics. Yet statisticians themselves are frustrated by the treatment of their products in the media and political arena, and wage a constant battle to ensure statistics are not freighted with a weight of meaning they cannot really bear. Economists' role in this dialectic is partly mediation between published statistics and political and public understanding (economists advise governments and communicate publicly as authorities); and partly mediation in the other direction between developments in economic structure and the public or political reaction to them and the intellectual framework for statistical definitions. Again, the analysis and exploration of these relationships is a rich avenue for future research.

\section{The political economy 'game'}

This real life feedback between the political world and the statistical, each framed in terms of prevailing economic theories, means the 'game' of economic policy settles into an equilibrium from which it is hard to dislodge the players. As Kaushik Basu puts it (in the context of the legal game rather than statistical standard setting), "The only way the law can affect behavior and outcomes is by deflecting society from one (pre-existing) equilibrium to another equilibrium, an 'equilibrium' being a choice of behavior on the part of each player that is optimal given that each player believes that the others will do as specified in the equilibrium." 43 For 'law' read 'national statistical standard'. A statistical standard - the classifications, definitions and measurements - sets people's beliefs in the economic 'game of life', and it is by shifting all players' beliefs that a new focal point can be attained. ${ }^{44}$ As Basu suggests, this setting of a focal point occurs by affecting players' beliefs about what other participants will do, and also by affecting their beliefs about others' beliefs: "We are all, for good or bad, citizens of the republic of beliefs."

In this law-and-economics context, a new law is more likely to overturn a pre-existing social norm if almost everybody believes laws must always be obeyed. In the national statistics context, a new framework (say a dashboard) is more likely to overturn the old focal point (GDP growth) if almost everybody agrees that there is a better conceptual framework, a consensus economic theory with the authority of 'economic law' in this domain, justifying the new framework. Keynesian macroeconomic theory played this role in the development of the SNA in the 1940s. An alternative approach would be to follow Akerlof and Snower in regarding narratives as a means of understanding the world and focusing attention: "Narratives thereby have a strong influence on our economic decisions, since we can only make choices with regard to the domain of possibilities that lies within our field of attention." ${ }^{45}$ Economic decisions are made, and political outcomes determined, with respect to the objects of choice we pay attention to; narratives make these choices social.

Online paper for World Economics Association's Conference on the Political Economy of Economic Metrics, 2013, http://peemconference2013.weaconferences.net/wp-

content/uploads/sites/9/2013/01/WEA-PEEMconference2013-Bos.pdf (13/5/16)

${ }^{43}$ Kaushik Basu, The Republic of Beliefs, World Bank Working Paper 7259, May 2015. P 15.

${ }^{44}$ Schelling 1963, Binmore 1994.

${ }^{45} \mathrm{G}$ Akerlof and D Snower, Bread and Bullet, CEPR Discussion Paper no. 11132, February 2016. 
Is there a tipping point for the adoption of new statistical standards by the international community? Consider the analogy to the diffusion of a new technology, where initially few people are willing to use the innovative technology, but at a certain point the majority will quickly follow the lead of early adopters. The question here is how many countries' official statistical communities would need to switch to a new set of standards for this 'tipping' to occur, and if it is a sub-set of the total, which countries? To address these questions, we need to understand the switching incentives for each country and the way these are affected by other countries' decisions. Even if every one individually can see great merits in switching, for all the reasons described above, the costs of departing from the existing standard can mean there is no incentive for any single one of them to act. We can approach this co-ordination problem either by considering the network of statistical agencies, or by asking whether there is a small enough 'tipping set', created by strategic complementarity, to move everybody from one equilibrium to another. Such a set can exist if the net benefits of switching rise the more other agents have already made the switch, so there is positive reinforcement for the decision. ${ }^{46}$ Why might this be realistic? First, because there are fixed costs in the conceptual and data gathering work involved in creating a new standard statistical framework; these would be spread more widely the more countries switch. Secondly, one of the costs of switching is criticism from anybody who is not convinced about the new framework - these political or reputational costs could be significant. But they will lose force the more countries agree to the make the switch.

Here, assume that all countries can benefit from the public good character of new statistical thinking (although if they do not switch in their own data gathering they will not harvest all the practical benefits such as scope for better policies and accountability). Assume also an implicit cost to not joining the switching coalition in the form of not influencing the new standards.

Each country has a benefit function, B, and a cost function, C, with net benefit

$$
B_{i}\left(S_{i,}, S_{-i}\right)-C_{i}\left(S_{i}, S_{-i}\right)
$$

where $S_{i}$, is country i's strategy and $S_{-i}$ the vector or strategies chosen by all other countries.

There are two possible strategies - not joining the new standard (0) and switching to the new standard (1). The gain for switching from 0 to 1 is

$$
\Delta=\left[B_{i}\left(1, S_{-i}\right)-C_{i}\left(1, S_{-i}\right)\right\}-\left\{B_{i}\left(0, S_{-i}\right)-C_{i}\left(0, S_{-i}\right)\right]
$$

or

$$
\Delta=\left[B_{i}\left(1, S_{-i}\right)-B_{i}\left(0, S_{-i}\right)\right\}-\left\{C_{i}\left(1, S_{-i}\right)-C_{i}\left(0, S_{-i}\right)\right]
$$

The incremental benefit term is non-negative (the new standard is better) and assumed to be independent of $S_{-i}$ because of the public good character of the new statistical standard. (If not independent, the term will be increasing in the number of

\footnotetext{
${ }^{46}$ Heal, Geoffrey M. and Kunreuther, Howard, Tipping Climate Negotiations (April 2011). NBER Working Paper Series, Vol. w16954, pp. -, 2011. Available at SSRN: http://ssrn.com/abstract=1810308
} 
other countries that switch.) The incremental cost term consists of a first term $\mathrm{C}_{\mathrm{i}}(1$, $\left.\mathrm{S}_{-i}\right)$ that is decreasing in the number of other switchers, and a second term $\mathrm{C}_{i}\left(0, \mathrm{~S}_{-i}\right)$, a cost of not switching, that is constant or increasing in the number of other switchers. If the latter is large enough, the overall gain can become positive. This result depends on the increasing difference property, which depends on the assumption that the cost of switching plausibly declines, and the cost of not switching is constant or increases, the larger the number of other switchers.

It can be shown that there is a 'tipping set', a sufficient number of switchers to make the decision to switch advantageous for all countries. The first step is a formalization of the 'increasing differences', the property of a payoff that increases the more additional switchers there are. In a game with $\mathrm{N}$ players each choosing a strategy from the set $\{0,1\}$, agents have payoff functions

$$
\mathrm{U}_{\mathrm{i}}:\{0,1\}^{\mathrm{N}} \rightarrow \mathrm{R}
$$

And for some $\varepsilon>0$

$$
S_{-i}^{\prime}>S_{-i} \text { implies } U_{i}\left(1, S_{-i,}^{\prime}\right)-U_{i}\left(0, S_{-i}^{\prime}\right) \geq \varepsilon+U_{i}\left(1, S_{-i,}\right)-U_{i}\left(0, S_{-i,}\right) \quad(A)^{47}
$$

This states that when one other agent switches, agent i's payoff increases by at least $\varepsilon$.

Now let $T$ be a subset of agents. If $\{1,1,1 \ldots\}$ is the only Nash equilibrium of the game in which all agents in $T$ choose (switching) strategy 1 , then $T$ is a tipping set of the game. It is a minimal tipping set if no subset is a tipping set. Heal and Kunreuther $(2010,2011)$ establish the proposition that with enough agents there is a tipping set of fewer than $\mathrm{N}-1$ members that tips the game from the original Nash equilibrium $\{0,0,0,0 \ldots\}$ to the new Nash equilibrium $\{1,1,1,1 \ldots\}$. The intuition is that there are external benefits to i from j's switching, such that a tipping set consists of agents generating sufficiently large external benefits.

Consider the $\mathrm{N}$-dimensional vector $\left(1,1^{\mathrm{k}}, 1_{\mathrm{i}}, 0^{\mathrm{N}-\mathrm{k}-2}\right)$ where superscripts denote the repetitions of the number superscripted and $S_{-i}=\left(1^{k}, 1_{j}, 0^{N-k-2}\right)$, and define

$\Delta_{j} U_{i}=\left[U_{i}\left(1,1^{k}, 1_{j}, 0^{N-k-2}\right)-U_{i}\left(0,1^{k}, 1_{j}, 0^{N-k-2}\right)\right]-\left[U_{j}\left(1,1^{k}, 0_{j}, 0^{N-k-2}\right)-U_{j}\left(0,1^{k}, 0_{j}, 0^{N-k-2}\right)\right]$

which is agent i's benefit from agent $j$ switching (assumed independent of the identity of j). From (A) above, it follows that:

$$
U_{i}\left(1,1^{k}, 0^{N-k-1}\right)-U_{i}\left(0,1^{k}, 0^{N-k-1}\right)>k \varepsilon+U_{i}\left(1,0^{N-1}\right)-U_{i}\left(0,0^{N-1}\right), k=\{1, \ldots N-1\}
$$

As all $0 s$ is a Nash equilibrium, then $U_{i}\left(1,0^{N-1}\right)-U_{i}\left(0,0^{N-1}\right)<0$

As all $1 \mathrm{~s}$ is a Nash equilibrium, then $\mathrm{U}_{\mathrm{i}}\left(1,1^{\mathrm{N}-1}\right)-\mathrm{U}_{\mathrm{i}}\left(0,1^{\mathrm{N}-1}\right)>0$

This means that the values in the sequence of differences (B) are initially negative and finally positive, so there is therefore a $\mathrm{k}$ such that

$$
k \varepsilon+U_{i}\left(1,0^{N-1}\right)-U_{i}\left(0,0^{N-1}\right)>0
$$

\footnotetext{
${ }^{47}$ Where in the vector $>$ indicates that at least one element is larger.
} 
and the first $\mathrm{k}$ agents form a tipping set. (Heal and Kunreuther in another paper prove that if a minimal tipping set exists, it consists of the first $k$ agents. ${ }^{48}$ )

This approach models the international negotiation of a switch to a new statistical standard as a game with at least two Nash equilibria. Switching incurs costs - the effort of devising and implementing the new standard, and perhaps other costs such as persuading the wider public to accept it - the existing equilibrium is sticky. But it might be possible to tip the 'game' to a new equilibrium once enough countries have initially switched to the new standard, because of the external benefits (the strategic complementarities) to others arising from their decision.

I assumed here that the identity of the early-adopter switchers was irrelevant. In the world of international negotiations, identity clearly does matter. The size of the required tipping set would surely be smaller if large and influential countries were among the early adopters. An alternative approach to a switch in global standards that does take account of the identity of early switchers would be to model the international network of national statistical entities. It is possible to explain very rare but very large switching cascades in terms of a network of interacting agents whose decisions are influenced by those of their neighbours. Duncan Watts shows that in a highly connected network, the nodes are locally stable, so that a cascade like the diffusion of a new norm or technical standard occurs rarely but is very large when it does occur (in contrast to a power law distribution for the size and frequency of cascades when the network is sparse).$^{49}$ In this case too, the agents face a binary decision (stay or switch, 0 or 1 ) with externalities.

In a network of $\mathrm{N}$ heterogeneous agents (or nodes) initially in state 0 , each has $\mathrm{k}$ neighbours (where $k$ varies from node to node). Each is assigned a threshold $\phi$ for switching to state 1 , drawn randomly from $f(\phi)$, where $f(\phi)$ is drawn from the unit interval and normalized (so that $\int_{0}^{1} \mathrm{f}(\phi) \mathrm{d} \phi=1$ ). Each agent is connected to its $\mathrm{k}$ neighbours with probability $p_{k}$ and the average number of neighbours is $z$. Suppose all agents start in state 0 and a small proportion $\phi_{0}$ switch to state 1 . The nodes then update their state in a random order according to whether or not their threshold has been exceeded. The threshold rule makes the agents locally interdependent, where the dependence is conditional on the proportion of the neighbourhood that has already switched. The model therefore captures natural features of the interdependent relationships between individuals in a professional community, where the influence of any one on others could depend on a range of factors such as personal contact or perceived credibility or importance of some countries.

As the decision is a function of the share of other agents who switch, there is again a threshold such that, when an agent gets to their personal threshold, the decision of just one more neighbor can tip them over. In this approach, the agents are heterogeneous. Watts notes: "The success or failure of an innovation may depend less on the number and characteristics of the innovators themselves than on the structure of the community of early adopters." It matters not only how many early adopters there are, but also how connected they are to each other and to the wider community. In contrast to many network models of percolating influence, in this

\footnotetext{
${ }^{48}$ Heal, Geoffrey and Howard Kunreuther. 2010. "Social Reinforcement: Cascades, Entrapment, and Tipping." American Economic Journal: Microeconomics, 2(1): 86-99.

${ }^{49}$ A Simple Model of Global Cascades on Random Networks, Duncan J. Watts Proceedings of the National Academy of Sciences of the United States of America, Vol. 99, No. 9 (Apr. 30, 2002), pp. 57665771Published by: National Academy of Sciences http://www.jstor.org/stable/3058573 7/4/16
} 
model there are either no cascades (because potential switchers are too isolated) or a global cascade. Normally, heterogeneous networks (with highly skewed degree distributions) are stable; but if a switch targets a node whose neighbours have a high probability of switching, then a global cascade can occur. This model assumes the network is random, which is not realistic but is made for tractability.

Assuming the network is sufficiently large and sparsely connected, suppose one node, the initiator, switches from state 0 to 1 . The condition for others to switch is that at least one immediate neighbour must have a switching threshold such that $\phi \leq 1 / \mathrm{k}$; agents meeting this condition are early adopters. Unless the initiator is sufficiently connected to early adopters, and the largest early adopting cluster is sufficiently connected to the remainder of the network, there will be no global cascade of the whole network to state 1 . Watts shows that in highly skewed networks a global cascade is most likely when the most connected nodes switch first. The selection of which initial node to target to bring about a switch depends on the network structure. When the network is dense, the stability of the individual nodes reduces the probability of a cascade: "The system displays a dramatic kind of robust-but-fragile quality... remaining almost completely stable throughout many shocks before exhibiting a sudden and giant cascade." ${ }^{.50}$ This network approach would suggest a standards switch in the international official statistics community will require leadership from some key, large countries; but if they provide it, a (near-)universal switch could occur quickly.

As the discussion in the previous section indicates, the model is a greatly simplified approach to a process of change involving several separate groups of players, each of the groups consisting of individuals with potentially conflicting views and interpretations. The channels of influence between groups differ too: voting, bureaucratic incentives, media. Developing a more complex model would surely be fruitful. Yet the simple model does seem to capture a useful insight into the process of switching from one standard to another; it is similar to what has happened in the past, as the next section describes.

\section{Historical origins of the present System of National Accounts}

Measurement of the aggregate economy for the purposes of government dates back to William Petty and Gregory King in the second half of the $17^{\text {th }}$ century, or even the Domesday Book, and for at least two centuries there were various efforts to measure the economic sphere of life. However, measurement always lags behind reality. For example, the 1871-85 Statistical Abstract for the United Kingdom contains 193 pages of figures on agricultural production and trade, such as details about which kinds of grains were being imported, from which countries, or the production of various exotic crops in the British colonies. ${ }^{51}$ It has just seven pages on mines, railways, canals and mills - this at the height of the Industrial Revolution.

The approach to economic measurement has always been shaped by the emergence of new political needs, including raising taxes, and also by prevailing economic thinking. Modern national income accounting has its roots in the 1930s and

\footnotetext{
${ }^{50}$ Watts, op cit, p5771

${ }^{51}$ Statistical Abstract of the United Kingdom in each of the last fifteen years from 1871-1885, facsimile edition published 1986 by Her Majesty's Stationery Office.
} 
Second World War. ${ }^{52}$ The crisis of the Great Depression and the imperatives of wartime production, combined with Keynes's influence on macroeconomic theory and policy, led to the concept of 'the economy' as an entity to be managed by the government, and to be measured by the new national income accounts developed by Richard Stone and others during and after the war. ${ }^{53}$

Simon Kuznets in the United States and Colin Clark in the United Kingdom had already worked during the 1930s on collecting the data and defining the concepts to use in building an aggregate measure of the economy. World War II made the effort more urgent. Keynes expressed his frustration about lacking estimates of the resources available for the war effort in his pamphlet How to Pay for the War: "The statistics from which to build up these estimates are very inadequate. Every government since the last war has been unscientific and obscurantist, and has regarded the collection of essential facts as a waste of money." ${ }^{254}$ During the war, and in the postwar years, as the measurement of national income became standardised into GNP and embedded in a framework of national accounts, the concept of aggregate economic output adopted differed profoundly from Kuznets' original intention. ${ }^{55}$ In his pre-war work, Kuznets had sought a national income definition that, "Would remove from the total the elements which, from the standpoint of a more enlightened social philosophy than that of an acquisitive society represent dis-service rather than service." ${ }^{56} \mathrm{He}$ proposed removing arms spending, most advertising, unequivocal 'bads' such as cigarette consumption, and illegal or anti-social activities, "a great many of the expenses involved in financial and speculative activities", and spending on the costs of an urban economic civilization, such as costly housing, or public transport - items that could be considered costs of 'doing business' as an economic agent in a complex modern society. He also proposed excluding much government expenditure, arguing that it too represented these kinds of 'intermediate' activities rather than final services to individuals. Another national income pioneer, Colin Clark, agreed, writing in his 1940 book The Conditions of Economic Progress, "Comparisons of economic welfare between one community and another, one economic group and another, one time and another, are the very framework of economic science. ${ }^{.57} \mathrm{~A}$ measure of economic welfare is exactly what economists need, he argued.

However, Kuznets' and Clark's emphasis on final goods and services of direct benefit to consumers meant wartime government expenditure would seem to be shrinking the economy, and so was resisted by key economists in the US Administration, with the active encouragement of Keynes. Their view was not simply pragmatic, however; it was also fundamentally informed by Keynes's theory. As the war drew to an end, the British economist Richard Stone, Canadian George Luxton and a BEA team including Milton Gilbert and George Jaszi met in Washington DC and settled on the

\footnotetext{
${ }^{52}$ D Coyle, GDP: A Brief But Affectionate History, Princeton University Press, 2014.

${ }^{53}$ D Hirschman, Inventing The Economy: Or how we learned to stop worrying and love the GDP, dissertation presented at University of Michigan, 2016.

54 J.M.Keynes, 'How to Pay for the War', 1940, reprinted in Essays in Persuasion, Royal Economic Society, 1972 (first publ 1951). The story of the role economic statistics played as part of the war effort has been told in Jim Lacey's 2011 book, Keep From All Thoughtful Men: How US Economists Won World War II. The book characteristically downplays the role of the British in the Allied victory.

${ }^{55}$ Described briefly in Coyle, GDP: A Brief But Affectionate History, Princeton University Press, 2014; see also Mitra-Kahn, Benjamin H. (2011). 'Redefining the Economy: how the 'economy' was invented 1620,' Unpublished Doctoral thesis, City University London, Chapter 9.

${ }^{56}$ Simon Kuznets, National Income 1919-1935, National Bureau of Economic Research, Cambridge MA, 1937. page 37.

${ }^{57}$ Colin Clark, The Conditions of Economic Progress, 1940, p26
} 
Keynes rather than the Kuznets approach. ${ }^{58}$ The meeting was the origin of the process of settling the national accounting framework by international consensus. The new national accounts were further embedded through Marshall Aid, as the US required the Organisation for European Economic Co-operation (the forerunner of the OECD, created to administer Marshall Aid funds) to monitor the recipient countries' GNP. The administrative machinery for creating national GNP then GDP figures through a UN-based standards setting process embedded the wartime 'victory' of the Keynesians, and the definition of the aggregate economy that was never intended to measure economic welfare. The origin of today's national accounting framework is a good example of the interplay between different groups of actors and between theory, measurement and reality, in specific historical and political circumstances, in setting the framework for economic statistics. By 1975, Hicks was able to state confidently: "If modern theory is to be effective, if it is to deal with the questions which we in our time want to have answered, the size and growth of the Social Product are among the chief things with which it must concern itself. It is of course the objective Social Product on which attention must be fixed. We have indexes of production; we do not have - it is clear we cannot have - an Index of Welfare." ${ }^{59}$

Yet the question of whether aggregate measures should try to capture simply the total amount of (monetary) activity or total economic welfare instead was an active discussion from the early 1940s, when the foundations for the current framework of national accounts were laid, into the 1950s. Precisely this debate about whether to measure welfare or just activity has cropped up recurrently in the shape of the environmental challenge to the policy focus on GDP growth, in alternatives such as the Human Development Index, and in the recent focus on happiness or well-being. However, there are two common confusions. One is that it is possible to separate positive and normative analysis, something still stated in every student textbook. ${ }^{60}$ Sir John Hicks for one insisted this was possible, and normative questions could be set to one side in analysing growth of the 'social product'. ${ }^{61}$ Yet although his argument that economic (productive and allocative) efficiency and distributional or economic welfare questions are separable was successfully challenged long ago, economists still consistently assume that they can focus on the positive and leave politicians to worry about normative consequences. ${ }^{62}$ In the arena of economic aggregates, this translates into a presumption that the technocratic business of economists is ensuring GDP growth is as fast as possible while the political process addresses normative questions of distribution and fairness. However, total social welfare depends on the distribution of output, as any aggregation of individual outcomes involves a distributional weighting, either explicit or (as with the HDI for instance) implicit.

\footnotetext{
58 J Lacey, Keep From All Thoughtful Men, Naval Institute Press, Annapolis, 2011; E Masood, The Great invention: The Story of GDP and Making (and Unmaking of the Modern World), Pegasus Books, 2016.

59 J.R.Hicks, 'The Scope and Status of Welfare Economics,' Oxford Economic Papers, Oxford University Press, vol. 27(3), pages 307-26, November 1975, p 324

${ }^{60}$ For example, N Gregory Mankiw Principles of Economics $4^{\text {th }}$ Edition, Cengage Learning, 2007, p148: "Whereas efficiency is an objective goal that can be judged on strictly positive grounds, equity involves normative judgments that go beyond economics and enter into the realm of political philosophy."

61 J.R.Hicks, 'The Scope and Status of Welfare Economics,' Oxford Economic Papers, Oxford University Press, vol. 27(3), pages 307-26, November 1975.

${ }^{62}$ T De Scitovksy, A Note on Welfare Propositions in Economics, Review of Economic Studies, Vol 9 Issue 1, November 1941, pp77-88. See also J de V Graaff, Theoretical Welfare Economics, Cambridge University Press, 1971.
} 
The second confusion is the frequent denial that real GDP growth is intended to measure improvements in economic welfare, while at the same time constantly using it as a welfare indicator. Economists and statisticians will often claim that GDP is not an economic welfare measurement, cannot ever be one, and was never intended as such; but simply measures aggregate economic activity in monetary terms. Using transacted prices, it has never included estimates of social surplus. Yet as soon as the nominal terms aggregate is converted using a price index into a real terms measure, to be compared at different points in time or space, it is used to address questions about the economic welfare of society. As Studenski noted in 1958: "[T]his is generally the only purpose of such comparisons." ${ }^{13}$ Even when the real aggregate is intended for short-term use in macroeconomic policy judgements, there is an implicit assumption that an increase corresponds well enough to an increase in social welfare - or why would it be the policy target? Moreover, the public conversation about real GDP growth constantly assumes it is valid shorthand for meaningful economic progress.

Hence the confusion in some current debate about measurement issues, because people are not always clear that the actual growth statistics are not a measure of total economic welfare, so some benefits of new technologies cannot be expected to show up in GDP growth, and conversely, some components of measured GDP do not contribute to economic welfare. This confusion is hardly surprising when so often economists slip (more or less unconsciously) between describing GDP growth in efficiency (or 'positive') language and normative or welfare language, and so rarely acknowledge that even 'efficiency' debates involve the normative aspects of how the statistics are complied.

\section{The growth turn}

Another key historical moment in the present use of national accounts statistics for policy purposes occurred around 1960 with a turn from concern with the level of output and employment to the growth rate. It too illustrates how change can come about. An analysis of the language used in (American) economic policy documents, textbooks and media shows this transition starting in the late 1950s. For example, the 1946 US Employment Act calls for the promotion of "maximum employment, production, and purchasing power." But by 1956 the parties' presidential platforms were focused on growth of output. ${ }^{64}$ This is interesting as an example of the way political imperatives shape both economic analysis and the construction and use of economic statistics. The Cold War is important in explaining the policy turn from levels to growth of GDP. After Khrushchev's famous 1957 speech boasting that, "Growth of industrial and agricultural production is the battering ram with which we shall smash the capitalist system," the capitalist governments led by the US responded to the challenge by emphasizing growth as the pre-eminent economic policy goal. With strong encouragement from the new Kennedy administration, the OECD's founding charter in 1961 embedded a GDP growth target for all its member countries. $^{65}$

\footnotetext{
${ }^{63}$ Studenksi op cit p 218.

${ }^{64}$ Hirschman, op cit.

${ }^{65} \mathrm{M}$ Schmelzer, The Hegemony of Growth: the making and remaking of the economic growth paradigm and the OECD 1948-2010, Cambridge University Press 2016. A Yarrow, Measuring America: How economic growth came to define American greatness in the late twentieth century, University of Massachussetts Press, 2010. M Ward Quantifying the World: UN Ideas and Statistics, Indiana University Press, 2004.
} 
Economic theory paralleled the world of economic policy in switching to a preoccupation with growth models. Robert Solow published his influential paper on growth theory in $1957 .{ }^{66}$ The number of articles in major economics journals referring to growth exploded in the 1950s (even allowing for the upward trend in the total number of articles published) ${ }^{67}$ This episode is a particularly striking example of the way politics plays a vital part in determining the construction of economic statistics and the attention paid to particular statistics. Equally, the GNP or GDP growth rate quickly became an important influence on political debate. Parties competed on platforms promising the highest growth rates. Academic economic theory validated the focus on economic growth, as indeed it has ever since. The earlier academic debate about the welfare foundations (or their absence) of the constructed economic statistics, which had lasted into the 1950s and is a prominent feature of Studenski's 1958 history of national income accounting, simply faded away. The economic welfare relevance of GDP growth is assumed. However, it is not obvious.

Consider the contrast (Figure 2) between the pattern of real GDP growth in Greece and Portugal in recent years. At present they have similar levels of real GDP per capita (in PPP terms). Greece's GDP per capita is still declining, as it has for several years, while Portugal's is broadly flat. However, the Greeks have enjoyed a substantial amount more output per capita than the Portuguese, for more than a decade. Which people are better off?

Figure 2: Real GDP per capita: Greece and Portugal

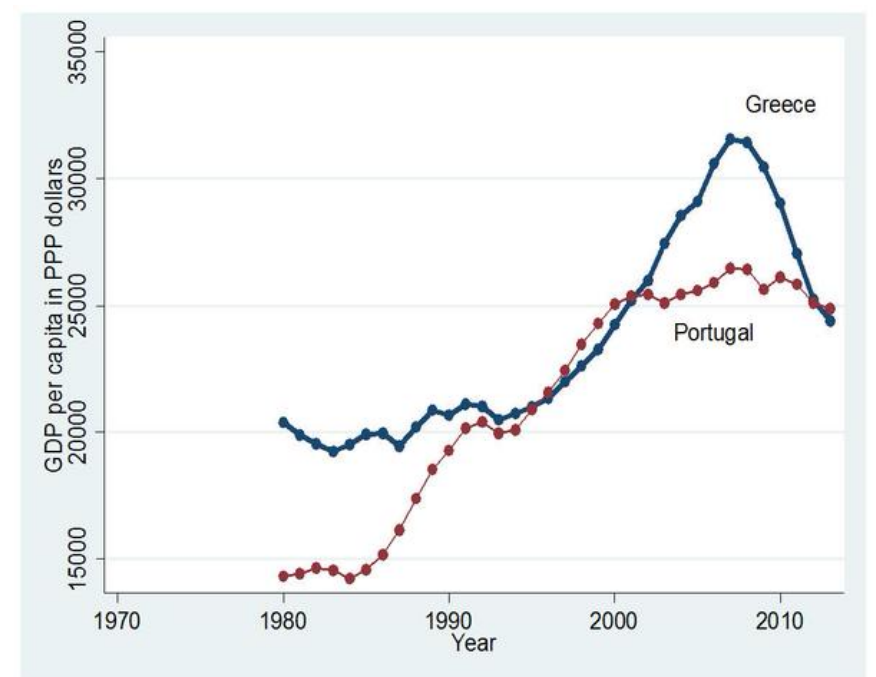

Source: OECD

Or consider (Figure 3) the contrast between Britain and China since 1970; the level of GDP per capita remains far higher in the UK but there has been substantially faster growth in China. Intuition says Britons remain better off. Does it then not matter that real GDP growth now in the UK is slow?

Figure 3: GDP per capita, Japan, China, UK

\footnotetext{
${ }^{66} \mathrm{R}$ M Solow, Technical Change and the Aggregate Production Function, Review of Economics and Statistics Vol. 39, No. 3 (Aug., 1957), pp. 312-320; Hirschman op cit.

${ }^{67}$ Yarrow, op cit, p 37
} 


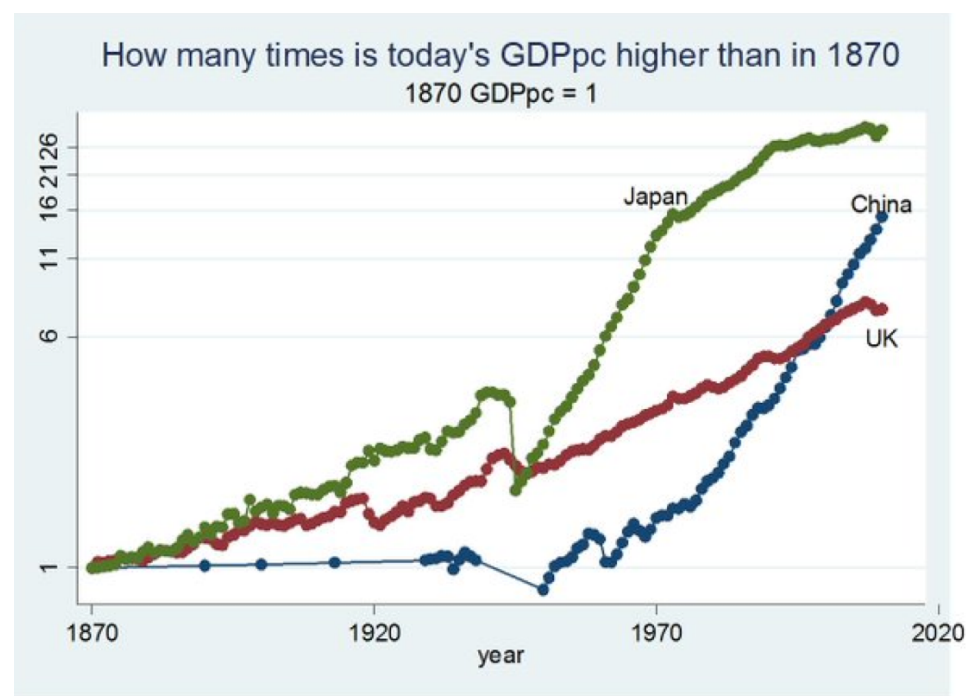

Source: The Maddison-Project, http://www.ggdc.net/maddison/maddison-project/home.htm, 2013 version. Note log scale.

There could be specific reasons why the rate of growth rather than the level of GDP would enter into the welfare calculus: innovation of new products and services; or hedonic adjustment and habit formation; or the political economy of distribution.

\section{(a) Innovation}

Increases in real GDP can consist of either more of the existing set of products and services or of new products and services (or new varieties), corresponding to the distinction in the innovation literature between process and product innovation. Economic welfare increases by assumption of non-satiation in standard models (albeit at a diminishing marginal rate) if people consume more of the same items. Faster growth due to process innovation delivers more of the same at a faster rate. More significant, though, in improving human well-being over the years is the pace of increase in real GDP due to faster product innovation, from life-changing and saving new products such as antibiotics, the internet, or mobile phones to seemingly more trivial but still highly valued ones such as nylon stockings, contact lenses or Facebook. Innovation is at the heart of economic growth. The measurement of economic output in practice, in terms of GDP, does not distinguish between the same additional real resources being spent on a tenth car and a genetically tailored chemotherapy pill. In terms of economic welfare, however, the difference is important. As noted above, there is no reason for (real) GDP and total economic welfare to coincide, and one of the areas of non-overlap is the consumer surplus arising from innovation.

\section{(b) Hedonic adaptation}

A second rationale for a policy targeting growth rather than levels is the well-known psychological phenomenon of hedonic adaptation. It is often said that chasing economic growth makes people unhappier. The suggested explanation is that people quickly adjust to new circumstances; every individual has a 'set point' of happiness from which departures rarely last more than a year or two. So the psychological benefits of an improved material standard of living soon wear off. ${ }^{68}$ However, several

\footnotetext{
${ }^{68}$ See eg 'Hedonic adaptation', Frederick, Shane; Loewenstein, George
} 
researchers have established that the positive correlation between economic growth and reported well-being exists at all income levels. ${ }^{69}$ The psychological adjustment mechanism can equally well explain this. When people have re-adjusted to their base level, they set off once again around the 'hedonic treadmill' to get another, albeit inevitably short term, boost to their sense of well-being. Estimates suggesting greater product variety delivers significant consumer surplus lend some support to this argument. Some psychologists argue that there is a 'paradox of choice' whereby individuals are less likely to make a purchase when there are many products for them to choose from, as the range of choice exceeds by too much their range of preferences. ${ }^{70}$ But this does not aggregate into a paradox of choice for the whole population, as there is no reason for different individuals' range of preferences will coincide, so there need not be a large gap between the combined preferences and the range of choice.

\section{(c) Political economy of redistribution}

If income redistribution is considered desirable on political or moral grounds, there are obvious reasons why this is easier when the economy is growing. One of the arguments in favour of targeting economic growth is that it is impossible to bring about a more equal distribution of incomes without it. One obvious reason is the link between growth and employment (and hence income). Furthermore, as Benjamin Friedman writes: "[T]he rising intolerance and incivility and the eroding generosity and openness that have marked important aspects of American society in the recent past have been, in significant part, a consequence of the stagnation of American middle class living standards during the last quarter of the $20^{\text {th }}$ century. ... Rising living standards nurture positive changes in political institutions and social attitudes." 71

These welfare considerations for a policy targeting economic growth as well as the level of GDP, in addition to the historical and political contingencies driving this policy shift in the late 1950s and early 1960s, are relevant to the debate about what the 'beyond' part of 'GDP and beyond' might include. Similarly, another example how change to the statistical framework can come about, drawing on the gap between GDP and economic welfare, and an evolving intellectual framework, is the introduction of the environmental 'satellite' account in the 1993 SNA. This move reflected the development of a consensus among stakeholders that the prevailing statistical standard ought to include a sustainability dimension. It was informed by scientific evidence and the growing interest in environmental economics. ${ }^{72}$ As noted earlier, some of the most fraught issues in the postwar discussion about measuring activity or welfare, and again in later debates about extending the SNA framework, are exactly the same as those re-emerging in today's debates, including the link between GDP growth and the environment, the location of the production boundary with respect to unpaid activity, and the treatment of externalities and of certain assets. $^{73}$

Kahneman, Daniel (Ed); Diener, Ed (Ed); Schwarz, Norbert (Ed), (1999). Well-being: The foundations of hedonic psychology. , (pp. 302-329). New York, NY, US: Russell Sage Foundation, xii, 593 pp.

\footnotetext{
${ }^{69}$ Stevenson, Betsey and Justin Wolfers. 2013. "Subjective Well-Being and Income: Is There Any

Evidence of Satiation?." American Economic Review, 103(3): 598-604.

${ }^{70}$ Schwartz, B, The Paradox of Choice, Harper Perennial 2004.

${ }^{71}$ B Friedman, The Moral Consequences of Economic Growth, Alfred A Knopf, 2005. Chapter 1.

72 See Vanoli (2005), pp164 ff.

${ }^{73}$ Note there was never an ambition to incorporate the entire range of factors contributing to human welfare. Pigou's 1920 definition from The Economics of Welfare, was the benchmark: "That part of social welfare which can be brought directly or indirectly in relation with the measuring rod of money," or,
} 


\section{Conclusion}

Moving from one focal point in the 'statistics and economy game' to another will be difficult because of the lock-in to the existing standards. In the current debate about whether and/or how to go 'beyond' GDP, this difficulty is very evident. There is no consensus about whether a single indicator or a dashboard is preferable, and if the latter, what indicators ought to be included in the dashboard. This debate is partly about the analysis and measurement of economic welfare, and partly about the political economy of national statistics.

Those arguing for an adjusted GDP or alternative single indicator believe the simplicity is essential for political traction. For example, Ehsan Masood argues for an environmental impact-adjusted GDP, as proposed initially by Costanza: "Although it is true that in our big data world, a dashboard of indicators would be easier now than ever to collect and attractive to display, most politicians feel overwhelmed by the quantity of information they are required to process. For this group of people, a composite index, a single number comprising a range of variables, is, if anything, more needed now than in the past." 74

Others support a dashboard, because a single indicator typically involves (usually implicit) weights combining multidimensional statistics (as these are usually of different units, not all monetary as in GDP).$^{75}$ This is a strong argument for working on a dashboard that can highlight the main trade-offs, while remaining reasonably parsimonious so that it can be presented intuitively and enable meaningful democratic debate. However, at present there is a proliferation of dashboards with a large number of different indicators and only partial overlap between the sets of indicators included.

Resolving this debate in terms of both economic analysis and political reality will be vital for the establishment of a new national statistical standard. The process will be a question of lengthy political and bureaucratic negotiation; as noted in this paper, there are important unresolved questions about the way these international discussions occur and attain broad public consent, including through the media and the democratic process. However, there are now significant pressures for change, a Kuhnian chasm between the existing statistical framework and the changed economic reality it is meant to represent; ${ }^{76}$ and so there is some reason to hope that it will be possible to build an international coalition sufficiently large to reach the tipping point for a move to a new framework.

\footnotetext{
"The balance of satisfactions from the use of the national dividend over the dissatisfactions involved in the making of it." (Quoted in Hicks, 1975, op cit, p 307.)

${ }^{74}$ Robert Costanza et al, 'The Value of the world's ecosystem services and natural capital,' Nature 387, 253-260 (15 May 1997); Ehsan Masood, op cit.

${ }^{75}$ For example, Martin Ravallion has pointed out that the widely-used Human Development Index incorporates implicit valuations of human life in different countries that would probably be considered unacceptable if they were explicit, as the index combines (among other things) life expectancy and GDP per capita and so involves an 'exchange rate' of life for money.Martin Ravallion, 2012. "Mashup Indices of Development," World Bank Research Observer, World Bank Group, vol. 27(1), pages 1-32, February.

${ }^{76}$ T Kuhn, The Structure of Scientific Revolutions, 1962.
} 


\section{References}

Timothy Aeppel, Silicon Valley Doesn't Believe U.S. Productivity Is Down, Wall Street Journal, 16 July 2015, http://www.wsj.com/articles/silicon-valley-doesnt-believe-u-s-productivity-isdown-1437100700

G Akerlof and D Snower, Bread and Bullet, CEPR Discussion Paper no. 11132, February 2016.

Kaushik Basu, The Republic of Beliefs, World Bank Working Paper 7259, May 2015

Charles Bean, Independent Review of Economic Statistics

https://www.gov.uk/government/publications/independent-review-of-uk-economic-statistics-

final-report

Tim Besley and Stephen Coate, 'Sources of Inefficiency in a Representative Democracy: A Dynamic Analysis', American Economic Review, 88, vol 1, 139-156, March 1998.

Kenneth Binmore, Game Theory and the Social Contract: Playing Fair, MIT Press, 1994.

Brett Christophers, Banking Across Boundaries: Placing Finance in Capitalism, Wiley/Blackwell 2013

Colin Clark, The Conditions of Economic Progress, 1940

Robert Costanza et al, 'The Value of the world's ecosystem services and natural capital,' Nature 387, 253-260 (15 May 1997); Ehsan Masood, op cit.

Diane Coyle, 'The Public Responsibilities of the Economist,' Tanner Lectures on Human Values, Oxford 2012.

Diane Coyle, GDP: A Brief But Affectionate History, Princeton University Press, 2014.

Diane Coyle, Talking About the National Accounts: Statistics and the Democratic Conversation, University of Manchester Economics Discussion Paper EDP-1506, May 2015. http://www.socialsciences.manchester.ac.uk/medialibrary/economics/discussionpapers/EDP1506.pdf Forthcoming in Review of Income and Wealth (2017).

Diane Coyle, 'Modernising Economic Statistics: Why It Matters', National Institute Economic Review, November 2015, pp. F4-F7.

Alain Desrosières, The Politics of Large Numbers: A History of Statistical Reasoning, Harvard University Press, 1998.

Richard A Easterlin. 'Does Economic Growth Improve the Human Lot? Some Empirical Evidence.' In Paul A. David and Melvin W. Reder, eds., Nations and Households in Economic Growth: Essays in Honor of Moses Abramovitz, New York: Academic Press, 1974.

Benjamin Friedman, The Moral Consequences of Economic Growth, Alfred A Knopf, 2005.

J de V Graaff, Theoretical Welfare Economics, Cambridge University Press, 1971.

Jochen Hartwig, 'On Spurious Differences in Growth Performance and on the Misuse of National Accounts for Governance Purposes', Review of International Political Economy, Vol. 13, No. 4 (Oct., 2006), pp. 535-558. 
Geoffrey Heal and Howard Kunreuther. 2010. "Social Reinforcement: Cascades, Entrapment, and Tipping." American Economic Journal: Microeconomics, 2(1): 86-99.

Geoffrey M. Heal and Kunreuther, Howard, Tipping Climate Negotiations (April 2011). NBER Working Paper Series, Vol. w16954, pp. -, 2011.

J.R. Hicks, The Scope and Status of Welfare Economics, Oxford Economic Papers, New Series, Vol. 27, No. 3 (Nov., 1975), pp. 307-326

Stable URL: http://www.jstor.org/stable/2662172

Daniel Hirschman, Inventing The Economy: Or how we learned to stop worrying and love the $G D P$, dissertation presented at University of Michigan, 2016.

HMSO, Statistical Abstract of the United Kingdom in each of the last fifteen years from 18711885, facsimile edition published 1986 by Her Majesty's Stationery Office

Tim Jackson, Prosperity Without Growth: Economics for a Finite Planet, Earthscan/Routledge, 2009.

J.M.Keynes, 'How to Pay for the War', 1940, reprinted in Essays in Persuasion, Royal Economic Society, 1972 (first publ 1951).

Thomas Kuhn, The Structure of Scientific Revolutions, first publ.1962

Simon Kuznets, National Income 1919-1935, National Bureau of Economic Research, Cambridge MA, 1937. page 37.

J Lacey, Keep From All Thoughtful Men, Naval Institute Press, Annapolis, 2011;

Michael Lewis-Beck and Mary Stegmaier, Economic Determinants of Electoral Outcomes, Ann Rev Polit Sci 2000:3, 183-219.

E Masood, The Great invention: The Story of GDP and Making (and Unmaking of the Modern World), Pegasus Books, 2016.

D Meadows et al, The Limits to Growth, first pub. Universe Books,1972;

Milanovic, Global Inequality: A New Approach for the Age of Globalization, Harvard University Press, 2016.

E Mishan The Costs of Economic Growth, revised edition, Oxford University Press ch 12, 1993

Mitra-Kahn, Benjamin H. (2011). 'Redefining the Economy: how the 'economy' was invented 1620,' Unpublished Doctoral thesis, City University London.

Daniel Mügge, 'Studying Macroeconomic Indicators as Powerful Ideas', mimeo, forthcoming in Journal of European Public Policy.

OECD, Income Inequality: The Gap between Rich and Poor (2015),

http://www.oecd.org/social/income-inequality-9789264246010-en.htm

Office for National Statistics, http://www.ons.gov.uk/ons/guide-method/user-guidance/wellbeing/about-the-programme/index.html

Theodore Porter, Trust in Numbers: The Pursuit of Objectivity In Science and Public Life, Princeton University Press 1995 
Martin Ravallion, 2012. "Mashup Indices of Development," World Bank Research Observer, World Bank Group, vol. 27(1), pages 1-32, February.

Rochet, Jean-Charles and Jean Tirole 'Two-Sided Markets: A Progress Report', The RAND Journal of Economics Vol. 37, No. 3 (Autumn, 2006), pp. 645-667

Thomas Schelling, The Strategy of Conflict, Harvard University Press, 1960.

M Schmelzer, The Hegemony of Growth: the making and remaking of the economic growth paradigm and the OECD 1948-2010, Cambridge University Press 2016

T De Scitovksy, A Note on Welfare Propositions in Economics, Review of Economic Studies, Vol 9 Issue 1, November 1941

R M Solow, Technical Change and the Aggregate Production Function, Review of Economics and Statistics Vol. 39, No. 3 (Aug., 1957), pp. 312-320

Stern Review http://webarchive.nationalarchives.gov.uk/20100407011151/http://www.hmtreasury.gov.uk/stern_review_report.htm accessed 29/1/16

Paul Studenski, The Income of Nations, New York University Press, 1958, pp158-159.

Adam Tooze, Statistics and the German State, 1900-1945: The Making of Modern Economic Knowledge, Cambridge University Press 2007

André Vanoli, A History of National Accounting, IOS Press, Amsterdam, 2005.

G Ward, (2015), "Is Happiness a Predictor of Election Results?", CEP Discussion Paper No. 1343.

M Ward Quantifying the World: UN Ideas and Statistics, Indiana University Press, 2004.

Duncan J. Watts, 'A Simple Model of Global Cascades on Random Networks', Proceedings of the National Academy of Sciences of the United States of America, Vol. 99, No. 9 (Apr. 30, 2002), pp. 5766-5771

A Yarrow, Measuring America: How economic growth came to define American greatness in the late twentieth century, University of Massachussetts Press, 2010. 